\title{
Strategi Desain Bukaan terhadap Pencahayaan Alami untuk Menunjang Konsep Bangunan Hemat Energi pada Rusunawa Jatinegara Barat
}

\author{
Riantiza Avesta, Atikah Dwi Putri, Rana Alya Hanifah, \\ Nurul Annisa Hidayat, M. Deivito Dunggio \\ Jurusan Arsitektur, Fakultas Teknik Sipil dan Perencanaan, ITENAS, Bandung \\ Email: riantiza@itenas.ac.id
}

\begin{abstract}
ABSTRAK
Indonesia terletak pada garis ekuator yang kaya akan sumber daya sinar matahari sepanjang tahun, sehingga pencahayaan alami merupakan aspek penting dalam bangunan. Perencana bangunan (arsitek) harus mempertimbangkan pemanfaatan pencahayaan alami yang optimal melalui bukaan pada bangunan dan disamping itu harus sesuai dengan standar kenyamanan visual. Bangunan yang baik tentunya harus memenuhi kaidah keberlanjutan (sustainability) melalui konsep bangunan hijau (green building). Hasil pengamatan objek studi kasus bangunan Rusunawa Jatinegara Barat, Jakarta, menunjukkan bahwa tingkat iluminasi setiap tingkat (level) lantai berbeda. Semakin tinggi level lantai, maka semakin besar peluang sinar matahari masuk ke ruangan melalui bukaan dan semakin tinggi tingkat iluminasinya. Tingkat iluminasi yang melebihi standar kualitas pencahayaan alami berkontribusi pada ketidaknyamanan visual berupa silau (glare). Kondisi silau yang terjadi pada beberapa unit hunian rusun mengakibatkan penghuni menutup bukaan secara konvensional dan lebih memilih menggunakan pencahayaan buatan sepanjang hari, menyebabkan bangunan tidak hemat energi, yang artinya tidak mendukung konsep keberlanjutan (bangunan hijau). Oleh karena itu, diperlukan strategi desain bukaan yang tepat agar pada tahap perencanaan selanjutnya dapat dijadikan sebagai rekomendasi desain yang memenuhi kriteria standar kenyamanan visual. Studi ini bertujuan untuk mengevaluasi pencahayaan alami pada unit hunian Rumah Susun Jatinegara Barat. Metode penelitian kuantitatif dilakukan dengan menggunakan software IES-VE v5.3.1, dimana salah satu alat analisa simulasinya yaitu radiance, dapat menghitung tingkat iluminasi pencahayaan alami dalam ruang. Sampel penelitian dipilih berdasarkan metode purposive sampling dengan pertimbangan perletakan unit dan ketinggian lantai.
\end{abstract}

Kata kunci: bangunan hijau, kenyamanan visual, desain bukaan, rumah susun

\begin{abstract}
Indonesia lies on the equatorial line that is rich in sunlight throughout the year, sothat natural lighting is an important aspect of buildings. The building planners (architects) should consider the optimal use of natural lighting through openings in the building and in addition must conform to visual comfort standards. A good building must meet the principles of sustainability through the concept of green building. The observation of the case study, teh building of Rusunawa Jatinegara Barat Jakarta, shows that the level of illumination of each floor level is different. The higher the floor level, the greater the chances of sunlight entering the room through openings and the higher the illumination rate. Illumination levels that exceed natural lighting quality standards contribute to the visual discomfort of glare. Glares that occur in some tower units result in residents closing the openings conventionally and prefer to use artificial lighting throughout the day, causing the building not energy efficient, which means it does not support the concept of sustainability (green building). Therefore, it is necessary to design a proper opening in the next planning stage, which can be used as a design recommendation that meets the criteria of visual comfort standards. This study aims to evaluate natural lighting in residential units of Rumah Susun Jatinegara Barat. Quantitative research method is done by using IES-VE v5.3.1 software, where one of the simulation tool, that is radiance, can calculate the level of illumination of natural lighting in unit's area. The sample was chosen based on purposive sampling method with consideration of unit placement and floor height.
\end{abstract}

Keywords: green building, visual comfort, design openings, apartment 


\section{PENDAHULUAN}

Indonesia terletak pada garis ekuator yang kaya akan sumber daya sinar matahari sepanjang tahun, sehingga pencahayaan alami merupakan aspek penting dalam bangunan. Nick Baker pada papernya mengatakan bahwa, bangunan yang menerima cahaya matahari adalah hal mendasar bagi arsitektur[1]. Para perencana bangunan (arsitek) harus mempertimbangkan pemanfaatan pencahayaan alami yang optimal melalui bukaan pada bangunan dan disamping itu harus sesuai dengan standar kenyamanan visual, dimana kenyamanan visual di dalam bangunan, menurut Tri Harso Karyono, terkait dengan intensitas cahaya atau level penerangan (daylight level) dalam satuan lux, kontras (contrast) dan silau (glare). Seseorang akan merasa nyaman secara visual ketika intensitas cahaya yang jatuh pada benda atau masuk ke dalam ruangan cukup [2]. Kualitas pencahayaan alami yang tidak sesuai dengan standar akan mengakibatkan aktifitas tidak berjalan dengan baik. Ruangan dengan pencahayaan yang kurang memadai tentu tidak menunjang kelancaran aktifitas, demikian pula sebaliknya, jika pencahayaan berlebihan pun akan mengakibatkan ketidaknyamanan visual yaitu efek silau (glare).

Pada proses perancangan, faktor orientasi matahari berpengaruh terhadap perletakan massa bangunan dimana pengaturan perletakan, bentuk dan ukuran bukaan menjadi salah satu tantangan bagi perencana bangunan, karena arah jatuh sinar matahari menjadi pertimbangan penting dalam optimalisasi pencahayaan alami di siang hari. Rumah Susun Jatinegara Barat yang merupakan hasil sayembara, yang dilakukan atas kerjasama Ikatan Arsitek Indonesia, Pemerintah Provinsi DKI Jakarta dan Kementrian Pekerjaan Umum, selayaknya merupakan perencanaan bangunan yang terpilih dan terbaik dalam berbagai aspek dan menjadi proyek percontohan perencanaan rumah susun lainnya. Bangunan yang baik tentunya harus memenuhi kaidah keberlanjutan (sustainability) melalui konsep bangunan hijau (green building). Tony Rigg berpendapat bahwa konsumsi energi adalah isu utama sustainability pada perancangan bangunan dan merupakan bagian dari kepentingan global [1].

Berdasarkan pengamatan awal Rusunawa Jatinegara Barat, khusus pada unit hunian salah satu dari dua menara yang ada, cahaya matahari yang masuk melalui bukaan tidak merata dan cenderung menyebabkan silau bagi penghuni di dalamnya. Silau (glare) pada penerangan alami adalah kesulitan melihat karena adanya cahaya cemerlang, baik yang merupakan cahaya matahari langsung, cahaya langit maupun hasil pantulan [3]. Kondisi silau yang terjadi pada beberapa unit hunian rusun mengakibatkan penghuni menutup bukaan secara konvensional dan lebih memilih menggunakan pencahayaan buatan sepanjang hari. Hal ini tentu tidak menunjang optimalisasi pencahayaan alami, karena sesungguhnya cahaya matahari itu gratis/tanpa biaya. Pencahayaan buatan menggunakan listrik dan penggunaannya pada siang hari termasuk kedalam pemborosan energi. Bangunan yang tidak hemat energi artinya tidak mendukung konsep keberlanjutan (bangunan hijau). Terkait hal tersebut, maka tujuan studi ini adalah mengurangi pemakaian pencahayaan buatan pada studi kasus diakibatkan adanya ketidaknyamanan visual (silau/glare).

\section{METODOLOGI}

Studi ini menggunakan metode penelitian kuantitatif dengan melakukan evaluasi perhitungan tingkat pencahayaan alami pada fungsi ruang unit hunian rumah susun melalui bukaan. Alat simulasi (simulation tools) berupa software IES-VE v5.3.1 akan mengukur level pencahayaan alami pada model unit yang ditentukan, kemudian hasil simulasi diuji dan dibandingkan dengan standar SNI pencahayaan rumah tinggal. Tingkat iluminansi yang tidak sesuai dianalisa dan dilakukan ujicoba strategi desain yang sesuai pada desain bukaan agar memenuhi kriteria standar kenyamanan visual.

\subsection{Objek Studi}

Bangunan Rumah Susun Jatinegara Barat terletak di Jakarta Timur, yang dibangun pada Tahun 2013 ini, terdiri atas 2 tower pada lahan seluas $7.460,17 \mathrm{~m}^{2}$, dimana keseluruhannya berjumlah 520 unit hunian. Luas tiap unitnya sama dengan tipe $30 \mathrm{~m}^{2}$ [4]. 


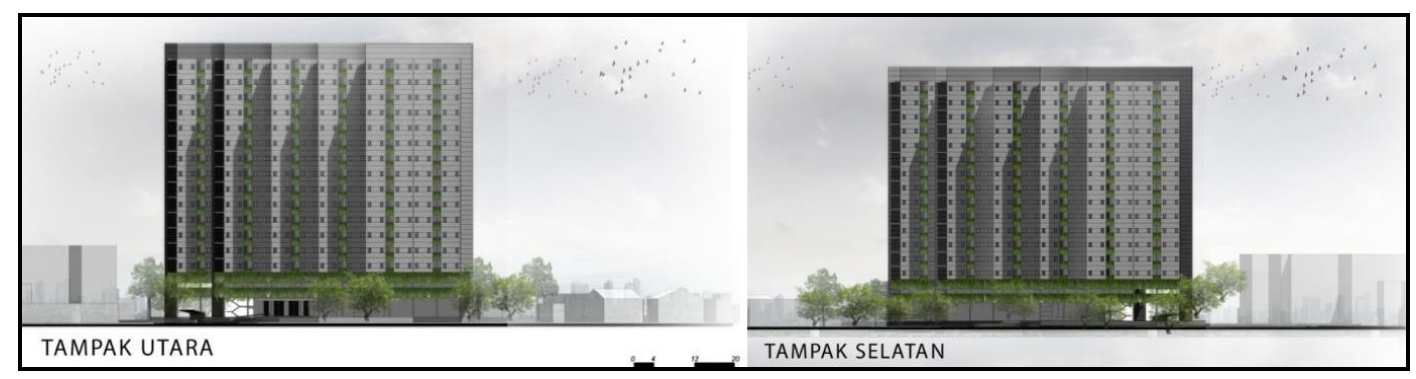

Gambar 1. Tampak Rusunawa Jatinegara Barat

\subsection{Pencahayaan/Penerangan Alami Siang Hari (PASH)}

Dalam perencanaan awal suatu bangunan, arah jatuh sinar matahari sangat mempengaruhi terhadap kinerja bangunan. Nurlaela Latifah pada bukunya menyatakan bahwa potensi pemanfaatan Pencahayaan Alami Siang Hari (PASH) adalah untuk kenyamanan visual dan konservasi energi. Kenyamanan visual dapat diperoleh melalui optimasi pemanfaatan cahaya alami dan desain bukaan yang tepat, agar cahaya alami yang diperoleh sesuai kebutuhan kerja visual, sedangkan konservasi energi dapat dicapai karena pemanfaatan cahaya alami dapat mereduksi hingga $20 \%$ total kebutuhan pemakaian energi listrik untuk pencahayaan buatan [3]. Namun, PASH pun memiliki tiga kendala utama, yaitu; pertama, pada saat gelap (mendung/hujan) penerangan buatan tetap harus digunakan; kedua, sumber cahaya (langit) bervariasi tingkat iluminasi nya, pada saat keadaan langit mendung/gelap, jendela dengan ukuran besar cukup optimal menerima cahaya alami, namun pada keadaan langit terang, cahaya menjadi terlalu banyak; ketiga, jika cahaya alami diterima dari sisi ruangan, tingkat pencahayaan yang dekat dengan jendela biasanya akan jauh lebih tinggi dari yang diperlukan. Kendala kedua dan ketiga adalah kondisi-kondisi yang pasti akan menghasilkan tingkat pencahayaan berlebih (over-illumination) [1]. Pemanfaatan PASH dapat dioptimalkan dengan memperhatikan faktor-faktor yang menunjang strategi dasar dalam perencanaan bukaan cahaya pada bangunan, antara lain sebagai berikut [3]: (1) Orientasi Bangunan dan Bukaan Cahaya, (2) Alokasi Ruang dan Bukaan Cahaya, (3) Luas Bukaan Cahaya.

\subsubsection{Orientasi Bangunan dan Bukaan Cahaya}

Pada daerah tropis dengan intensitas matahari sepanjang tahun, orientasi bangunan sangat berpengaruh signifikan terhadap pencahayaan di dalam bangunan. Secara ideal, sedapat mungkin menghindari arah matahari langsung pada arah barat dan timur, akan tetapi orientasi demikian tanpa dibarengi dengan cahaya yang cukup mempunyai resiko ruangan-ruangan pada bangunan menjadi gelap.

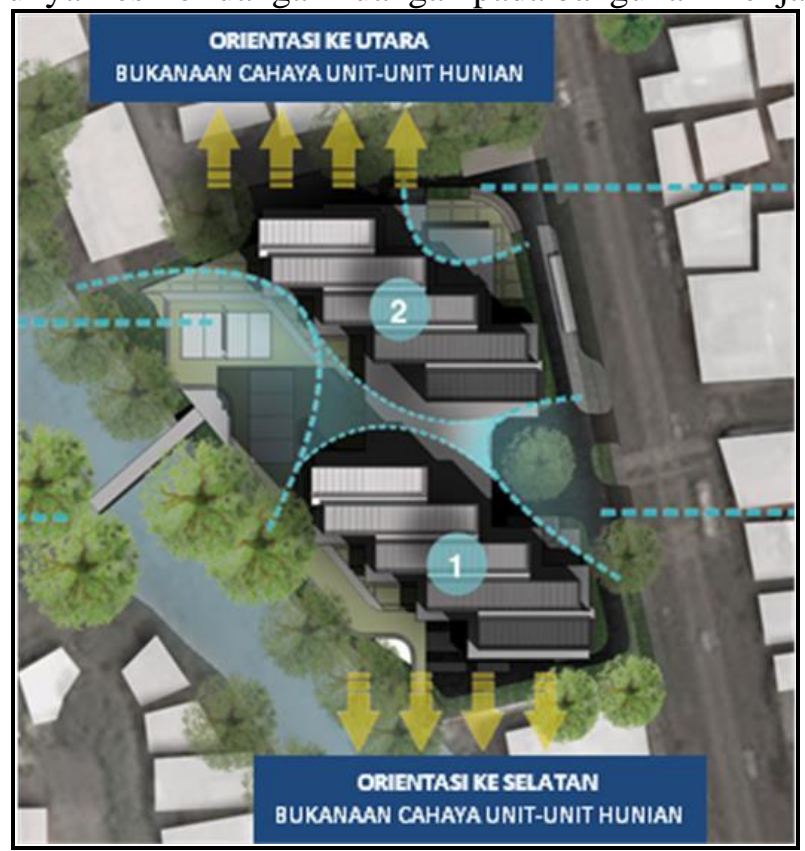

Gambar 2. Orientasi Layout Rusunawa Jatinegara Barat 
Orientasi yang paling baik pada daerah tropis adalah panjang bangunan memanjang Timur ke Barat, sehingga diharapkan cahaya yang masuk adalah cahaya dari hasil pantulan dan bukan cahaya langsung yang panas. Orientasi bukaan cahaya pada Rusunawa Jatinegara adalah menghadap Utara dan Selatan sementara pada bagian Timur dan Barat bangunan desain fasade dibuat masif.

Fasade bagian Barat dan Timur bangunan dirancang dengan sedikit bukaan pada huniannya, Sementara pada area publik yaitu lantai satu dan dua, bukaan lebih banyak karena berfungsi sebagai ruang bersama atau ruang berkumpul sehingga sirkulasi udara dan cahaya lebih banyak dibutuhkan. Selain itu orientasi bangunan menghadap ke bagian Barat dan Timur bangunan karena jalan masuk utama dari Jalan Jatinegara Barat berada di bagian Timur bangunan.

Bangunan Rusunawa ini memiliki bentuk koridor double loaded sehingga unit-unit di dalamnya memiliki 2 orientasi, yaitu menghadap Selatan dan Utara. Bukaan cahaya pada unit Rusunawa Jatinegara hanya terdapat pada bagian Utara dan Selatan bangunan saja (lihat Gbr. 2).

\subsubsection{Alokasi Ruang dan Bukaan Cahaya}

Ruang-ruang didalam rumah susun idealnya memang mempunyai akses langsung terhadap ruang luar untuk memaksimalkan PASH. Ruang yang terpaksa menggunakan pencahayaan buatan, dipilih fungsifungsi yang tidak sering dipakai, diantaranya adalah kamar mandi, dapur atau gudang. Beberapa ruangan yang harus mempunyai akses terhadap ruang luar langsung diantaranya adalah ruang kamar tidur, ruang keluarga, ruang tamu atau ruang kerja.

Berdasarkan data di lapangan, ruang-ruang didalam Rusunawa Jatinegara Barat mempunyai akses langsung terhadap ruang luar untuk memaksimalkan pencahayaan siang hari. Ruang yang terpaksa menggunakan pencahayaan buatan adalah ruang dengan fungsi-fungsi yang tidak sering dipakai, diantaranya adalah kamar mandi dan dapur. Beberapa ruangan yang mempunyai akses terhadap ruang luar langsung diantaranya adalah ruang kamar tidur, ruang tamu dan tempat jemuran.

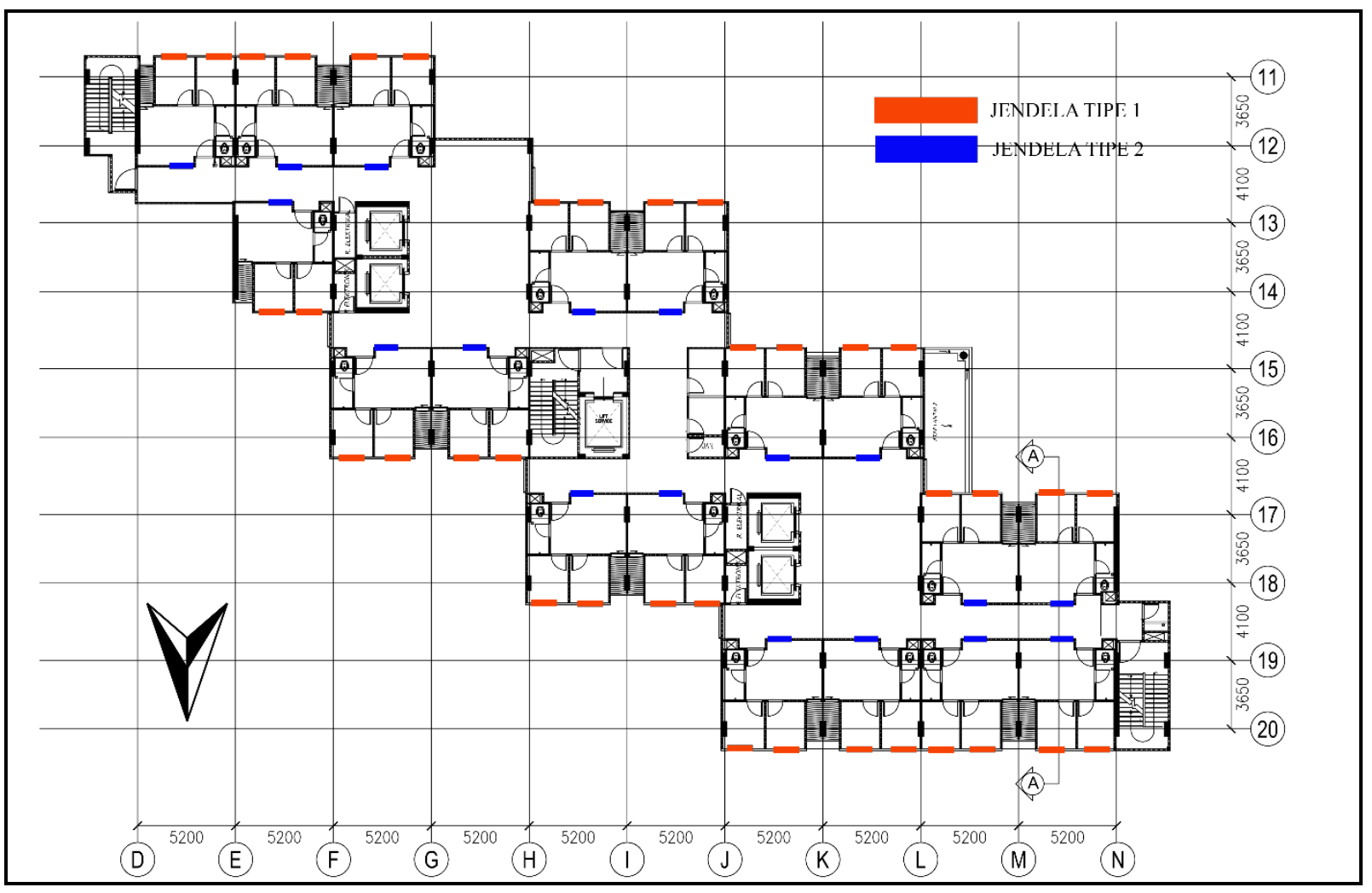

Gambar 3. Alokasi Fungsi Ruang Terkait Bukaan pada Rusunawa 
Bukaan cahaya pada hunian di tempatkan pada area kamar tidur masing-masing sebanyak satu buah. Selain itu bukaan juga terdapat di salah satu sudut dapur, tetapi pada bagian ini bukaan cahaya tidak langsung terkena sinar matahari langsung melainkan mengarah ke koridor sehingga tidak menghasilkan sumber cahaya pada bukaannya.

Letak bukaan pada unit Rusunawa Jatinegara ini terdapat dua jenis, yaitu bukaan yang menghadap keluar bangunan dan bukaan yang menghadap kearah koridor. Pencahayaan alami di dapat dari bukaan yang menghadap keluar bangunan sementara bukaan yang menghadap ke arah koridor tidak menghasilkan pencahayaan alami. (Lihat Gambar 3 dan Gambar 4)

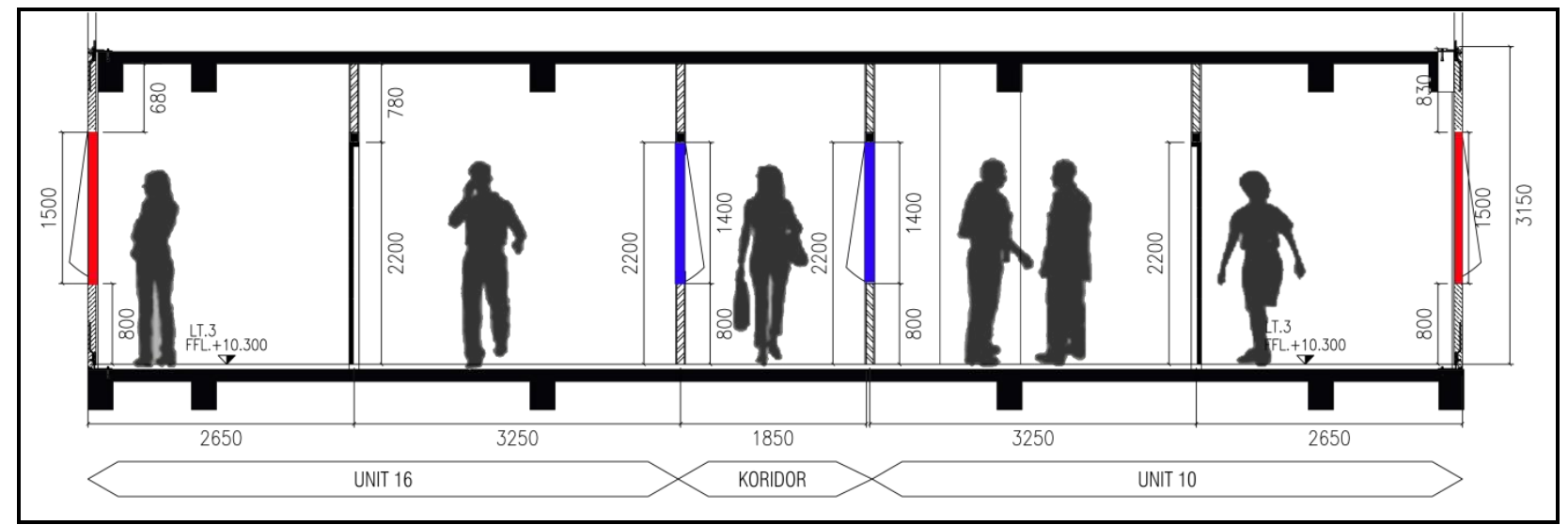

Gambar 4. Alokasi Bukaan Tipe 1 (Fasade Bangunan) dan Tipe 2 (Koridor)

\subsubsection{Luas Bukaan Cahaya}

Cahaya yang masuk kedalam ruangan kualitasnya berbeda, baik dilihat dari intensitasnya berdasarkan bidang pantul maupun cahaya langsung. PASH masuk melalui jendela atau bukaan melalui tiga komponen, yaitu: (1) Cahaya matahari langsung; (2) Cahaya pantulan langit; (3) Pantulan dari permukaan bawah dan bangunan sekitarnya [1].

Jenis bukaan jendela yang dipakai ialah jenis jendela casement atau jendela yang dibuka dengan mendorong bagian bawah.
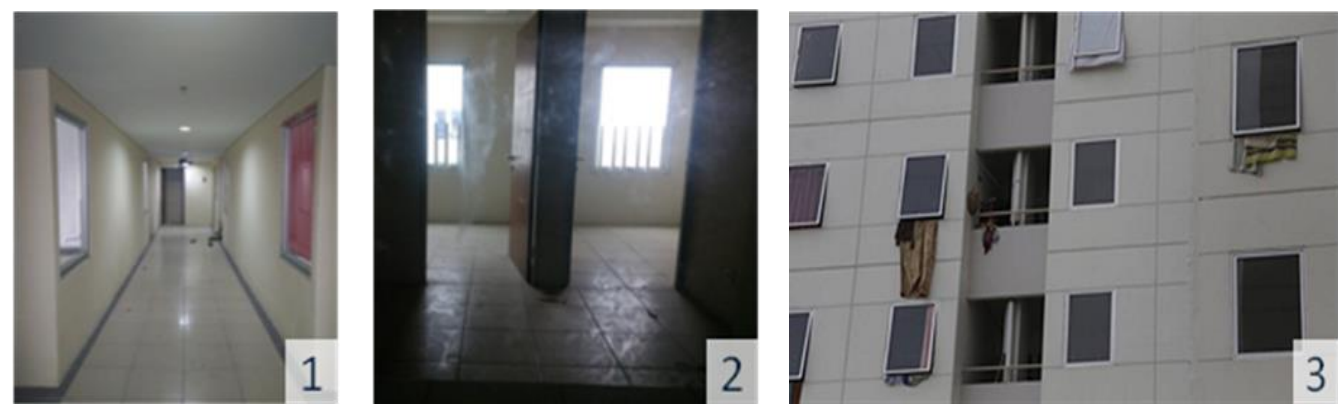

Gambar 5. Foto Interior dan Eksterior Rusunawa Jatinegara Barat terkait Bukaan

Dari hasil pengamatan dan pengukuran langsung, didapatkan bahwa terdapat dua tipe bukaan jendela pada Rusunawa yaitu sebagai berikut : 
Jendela Tipe 1

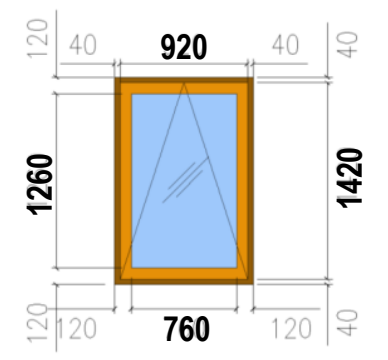

- Luas Bukaan : 1.159,200 mm

- Jenis Bukaan: Casement (jendela yang dibuka dengan mendorong bagian bawah)

- Jenis Kaca : Kaca bening tidak berwarna

- Tebal Kaca : $6 \mathrm{~mm}$
Jendela Tipe 2

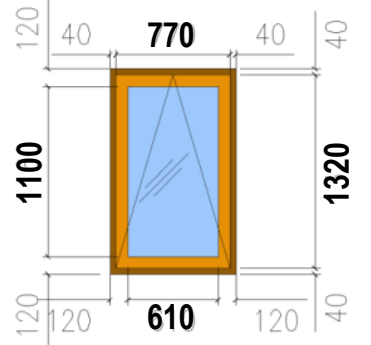

- Luas Bukaan : 707,600 mm

- Jenis Bukaan: Casement (jendela yang dibuka dengan mendorong bagian bawah)

- Jenis Kaca : Kaca bening tidak berwarna

- Tebal Kaca : $6 \mathrm{~mm}$

\section{Gambar 6. Spesifikasi Jenis dan Tipe Jendela pada Rusunawa jatinegara Barat}

\subsection{Simulasi}

\subsubsection{Simulasi Software IES-VE}

IES-VE (Integrated Environment Solution - Virtual Environment) adalah pengembangan software analisa Fisika Bangunan yang memiliki kantor pusat di UK, tepatnya di kota Glasgow, Skotlandia. Software ini menitikberatkan pada analisa smart and green building. Kelebihan dari software ini terletak pada kecepatan hasil rendering dan kemudahan dalam mengedit model 3D. Selain itu analisa yang dapat dilakukan oleh software ini sangat beragam dan lebih mendetail. IES-VE v5.3.1 adalah sistem terintegrasi yang fleksibel untuk penilaian kinerja yang membawa produktivitas dan keunggulan untuk setiap aspek dari desain bangunan yang berkelanjutan. Alat simulasi desain yang digunakan dalam IES-VE v5.3.1 untuk penelitian ini adalah model IT dan radiance [5].

\subsubsection{Model Simulasi}

Pemilihan sampel unit hunian yang akan di analisis pertama di pilih berdasarkan letak lantai yang akan di ambil yaitu pada lantai 3, lantai 10 , dan lantai 16 , berdasarkan pada letak hunian yang paling bawah, tengah dan paling atas. (Lihat Gambar 7)

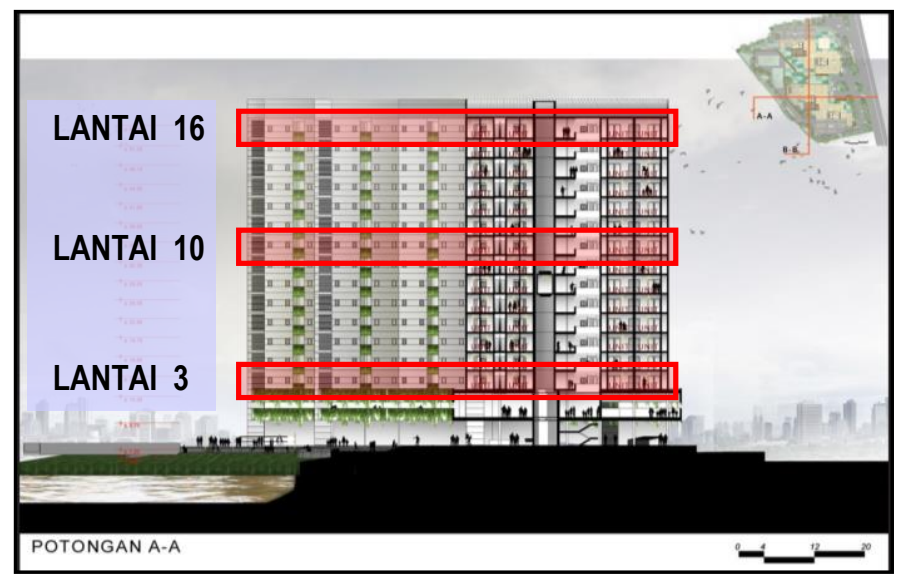

Gambar 7. Pemilihan Sampel ditinjau dari Gambar Potongan Rusunawa Jatinegara Barat

Selanjutnya, pemilihan objek pada unit hunian berdasarkan purposive sampling dengan mengambil perwakilan unit hunian di lantai 3 (bawah), lantai 10 (tengah), dan lantai 16 (atas) Analisa sampel unit yang diambil adalah unit B, D, F, L, N dan R yang dipilih berdasarkan unit hunian yang menghadap utara dan selatan dan unit hunian yang berada paling timur tengah dan barat. (Lihat Gambar 8) 


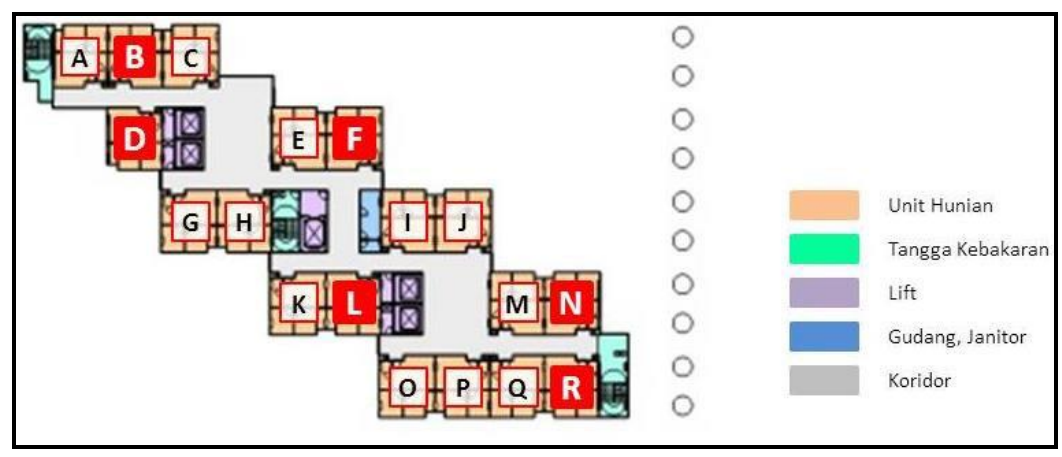

Gambar 8. Pemilihan Sampel ditinjau dari Denah Hunian Rusunawa Jatinegara

Standar Kuat Penerangan (lux) yang dibutuhkan pada bangunan rumah susun diatur dalam SNI 036575-2001, adapun standar lux yang diberlakukan untuk rumah tinggal adalah sebagai berikut [6]:

Tabel 1. Standar Kuat Penerangan (Lux) pada Rumah Tinggal

\begin{tabular}{l|c|c}
\hline FUNGSI RUANGAN & $\begin{array}{c}\text { TINGKAT } \\
\text { PENCAHAYAAN } \\
\text { (lux) }\end{array}$ & $\begin{array}{c}\text { KELOMPOK } \\
\text { RENDERASI } \\
\text { WARNA }\end{array}$ \\
\hline RUMAH TINGGAL : & & 1 atau 2 \\
\hline Teras & 60 & 1 atau 2 \\
\hline Ruang Tamu & $120 \sim 250$ & 1 atau 2 \\
\hline Ruang Makan & $120 \sim 250$ & 1 \\
\hline Ruang Kerja & $120 \sim 250$ & 1 atau 2 \\
\hline Kamar Tidur & $120 \sim 250$ & 1 atau 2 \\
\hline Kamar Mandi & 250 & 1 atau 2 \\
\hline Dapur & 250 & 3 atau 4 \\
\hline Garasi & 60 &
\end{tabular}

Terkait kuat penerangan pada tabel 1, dapat disimpulkan bahwa standar ideal nilai Kuat Penerangan (Lux) pada fungsi rumah tinggal adalah 120-250 lux.

\section{HASIL DAN PEMBAHASAN}

Simulasi dilakukan untuk mengetahui nilai Kuat Penerangan (lux) di dalam ruang fungsional pada unit hunian Rusunawa, pada waktu matahari berada pada titik equinox dimana waktu siang dan malam hari sama panjang serta sudut matahari pada deklinasi tertinggi dan terendah pada tanggal 21 Maret, 22 Juni, 23 September, dan 22 Desember. Jam pengukuran ditentukan pada jam 08:00, 12:00, dan 16:00 dengan pertimbangan kondisi pencahayaan minimal dan maksimal.

Simulasi kemudian dilakukan dengan model unit, yang menghasilkan nilai daylight level pada setiap titik yang diukur, sehingga terlihat kontur daylight nya. Adapun variabel material yang ditetapkan untuk diinput pada simulasi adalah sebagai berikut:

Tabel 2. Variabel Material pada Model Unit Simulasi

\begin{tabular}{c|c|c}
\hline Konstruksi & Spesifikasi & Material \\
\hline Dinding & Faktor Refleksi 70\% & Bata ringan finishing cat putih \\
\hline Kaca & Faktor Transmisi 100\% & Kaca bening tanpa warna \\
\hline Lantai & Faktor Refleksi 0,4 & Keramik Putih \\
\hline Plafond & Faktor Refleksi 0,1 & Plat lantai beton finishing cat putih \\
\hline
\end{tabular}


Dalam Radiance, CIE Model langit mendung (Overcast Sky) yang dipilih untuk mewakili iklim Indonesia. Simulasi ini menghasilkan nilai pencahayaan alami dalam ruang, tingkat pencahayaan minimum dan maksimum, dan area di atas ambang batas. Ambang batas yang ditetapkan untuk rumah tinggal diatur dalam 120 lux, untuk mewakili kamar tidur dengan aktivitas santai merata pada keseluruhan ruangan, dan diukur pada pada ketinggian bidang kerja $(0,75$ meter di atas permukaan lantai). Untuk mengetahui kedalaman penetrasi puncak siang hari, simulasi pencahayaan alami dalam model dilakukan pada bulan Maret, September, Juni, dan Desember pada pukul 12.00 WIB (siang hari), sedangkan untuk analisis silau, simulasi harus dijalankan pada pukul 08.00 WIB dan 16.00. Hasil simulasi kemudian akan dibandingkan dengan standar SNI pencahayaan alami pada rumah tinggal.

\subsection{Hasil Simulasi Pencahayaan Alami Siang Hari}

Hasil simulasi menunjukkan nilai Daylight Level pada setiap titik yang diukur, sehingga terlihat kontur daylight, dan ternyata nilai Daylight Level bervariasi. Berikut nilai intensitas cahaya hasil simulasi berdasarkan level lantai :

Tabel 3. Hasil Simulasi Iluminan (E) Ruang pada Unit Hunian

\begin{tabular}{|c|c|c|c|c|c|c|c|c|c|c|c|c|c|}
\hline \multirow{2}{*}{$\mathbf{E}$} & \multirow{2}{*}{$\mathbf{L T}$} & \multicolumn{3}{|c|}{21 Maret } & \multicolumn{3}{|c|}{22 Juni } & \multicolumn{3}{|c|}{23 September } & \multicolumn{3}{|c|}{22 Desember } \\
\hline & & 08.00 & 12.00 & 16.00 & 08.00 & 12.00 & 16.00 & 08.00 & 12.00 & 16.00 & 08.00 & 12.00 & 16.00 \\
\hline \multirow{3}{*}{$\begin{array}{c}\text { E Min } \\
\text { (lux) }\end{array}$} & 3 & 247 & 620 & 247 & 259 & 471 & 239 & 289 & 488 & 220 & 283 & 428 & 191 \\
\hline & 10 & 314 & 314 & 620 & 328 & 595 & 303 & 347 & 618 & 279 & 258 & 543 & 242 \\
\hline & 16 & 160 & 160 & 470 & 176 & 348 & 117 & 170 & 416 & 94 & 98 & 143 & 76 \\
\hline \multirow{3}{*}{$\begin{array}{c}\text { E Max } \\
\text { (lux) }\end{array}$} & 3 & 457 & 904 & 904 & 481 & 873 & 443 & 506 & 931 & 407 & 412 & 791 & 353 \\
\hline & 10 & 529 & 1048 & 1048 & 553 & 1003 & 512 & 587 & 1041 & 471 & 480 & 915 & 415 \\
\hline & 16 & 506 & 924 & 1048 & 553 & 1003 & 512 & 587 & 1041 & 471 & 480 & 915 & 411 \\
\hline \multirow{3}{*}{$\begin{array}{c}\mathrm{E} \\
\text { Average } \\
\text { (lux) }\end{array}$} & 3 & 348,50 & 732,7 & 551,3 & 389,00 & 697,17 & 353,67 & 364,25 & 696,00 & 318,83 & 318,00 & 639,17 & 283,58 \\
\hline & 10 & 403,67 & 596,7 & 810,2 & 403,00 & 792,83 & 397,17 & 448,10 & 817,58 & 362,83 & 375,50 & 734,67 & 315,25 \\
\hline & 16 & 373,2 & 566,8 & 785,9 & 390,0 & 723,6 & 357,9 & 433,5 & 782,2 & 324,7 & 322,2 & 629,7 & 274,9 \\
\hline
\end{tabular}

Hasil simulasi pada tabel 3 menunjukkan bahwa iluminan rata-rata paling rendah dalam ruangan adalah 76 lux, yang terjadi pada 22 Desember pukul 16.00 (pada kamar 2 unit B lantai 16 sisi Barat) dan iluminan tertinggi paling tinggi adalah 1048 lux, yaitu pada 21 Maret pukul 16.00 (pada kamar 2 unit $R$ lantai 10 sisi Timur).

Tabel 4. Hasil Simulasi Iluminan (E) Ruang pada Unit Hunian

\begin{tabular}{c|c|c|c|c|c|c|c}
\hline Lantai & Nama Unit & Kamar & Letak & $\begin{array}{c}\text { E avg } \\
\text { (lux) }\end{array}$ & Tanggal & Waktu & Peringkat \\
\hline 3 & $\mathrm{~L}$ & 1 & $\begin{array}{c}\text { Sisi Tengah } \\
\text { Orientasi Selatan }\end{array}$ & 513 & $\begin{array}{c}23 \\
\text { September }\end{array}$ & 12.00 & 3 \\
\hline 10 & $\mathrm{R}$ & 2 & $\begin{array}{c}\text { Sisi Barat } \\
\text { Orientasi Selatan }\end{array}$ & 568 & 21 Maret & 12.00 & 1 \\
\hline 16 & $\mathrm{R}$ & 2 & $\begin{array}{c}\text { Sisi Barat } \\
\text { Orientasi Selatan }\end{array}$ & 560 & 21 Maret & 12.00 & 2 \\
\hline
\end{tabular}




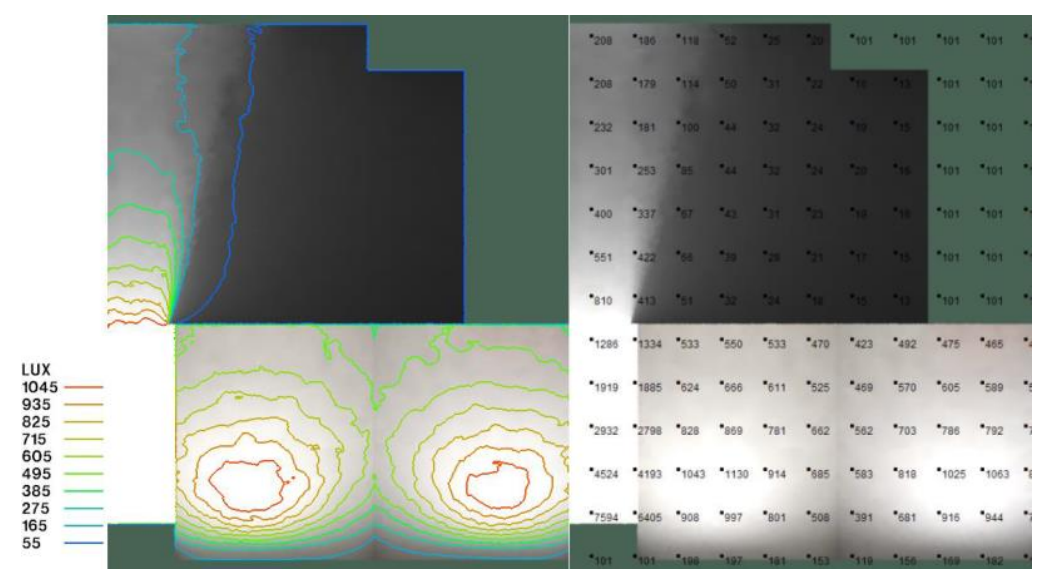

\section{Gambar 9. Denah Hasil Simulasi pada Unit Hunian dengan Iluminan Tertinggi}

Analisis Pencahayaan Alami Siang Hari menunjukkan bahwa fungsi unit hunian membutuhkan shading atau memperkecil bukaan cahaya karena pencahayaan alami yang masuk siang hari melebihi standar rumah tinggal. Simulasi model menunjukkan bahwa ukuran bukaan pada kamar tidur unit hunian terlalu besar. Di sisi lain dengan tingkat tinggi pencahayaan dalam ruangan siang hari beban radiasi panas juga tinggi dan memiliki risiko efek silau yang tinggi. Efek silau yang tinggi ini seringkali terjadi sehingga penghuni lebih sering menutup bukaan secara konvensional (menggunakan tirai) dan akibatnya lebih memilih menggunakan pencahayaan buatan dibandingkan pencahayaan alami.

Bukaan dirancang untuk memasukan cahaya alami ke dalam bangunan sedemikian rupa sehingga pencahayaan buatan tidak diperlukan pada siang hari. Matahari langsung di mata penghuni bangunan dapat menyebabkan kecacatan visual (silau/glare), yang mengganggu kemampuan penghuni untuk melihat dan melakukan pekerjaan. Penentuan tapak bangunan Rusunawa Jatinegara Barat sudah memaksimalkan paparan utara dan selatan fasade. Namun, beberapa pertimbangan diperlukan untuk memperbaiki kenyamanan visual.

\subsection{Strategi Desain}

Keberhasilan desain bukaan untuk pencahayaan alami bukan dilihat dari banyaknya cahaya yang masuk, akan tetapi lebih ditinjau dari aspek kenyamanan visual. Lebih lanjut, Nick Baker menyatakan bahwa pada cuaca yang panas, dimana penghuni mengalami kondisi tekanan panas, terdapat adanya keterkaitan secara psikologis bagi penghuni antara silau dengan kenyamanan termal juga, sehingga antisipasi silau menjadi dua kali lebih penting [1].

Hasil simulasi dengan software IES-VE menunjukan bahwa unit hunian fungsi kamar tidur Rusunawa jatinegara Barat melebihi standar pencahayaan alami pada rumah tinggal, sehingga diperlukan strategi antisipasi silau pada desain bukaan cahaya melalui pembatasan luas sumber silau, yaitu dengan cara sebagai berikut [3]:

(1) Memperkecil luas bukaan cahaya.

(2) Memberi pembayangan (shader) dan memperbesar dimensi pembayangan tersebut. Pembayangan dapat berupa sirip penangkal sinar matahari (SPSM).

(3) Memperkecil luas bukaan cahaya serta memberikan pembayangan berupa sirip penangkal sinar matahari (SPSM)

\subsubsection{Strategi Desain 1}

Strategi desain 1 yaitu dengan memperkecil luas bukaan cahaya pada kedua kamar tidur unit hunian menjadi $1,25 \mathrm{~cm} \times 0,9 \mathrm{~cm}\left(1.15 \mathrm{~m}^{2}\right)$. 

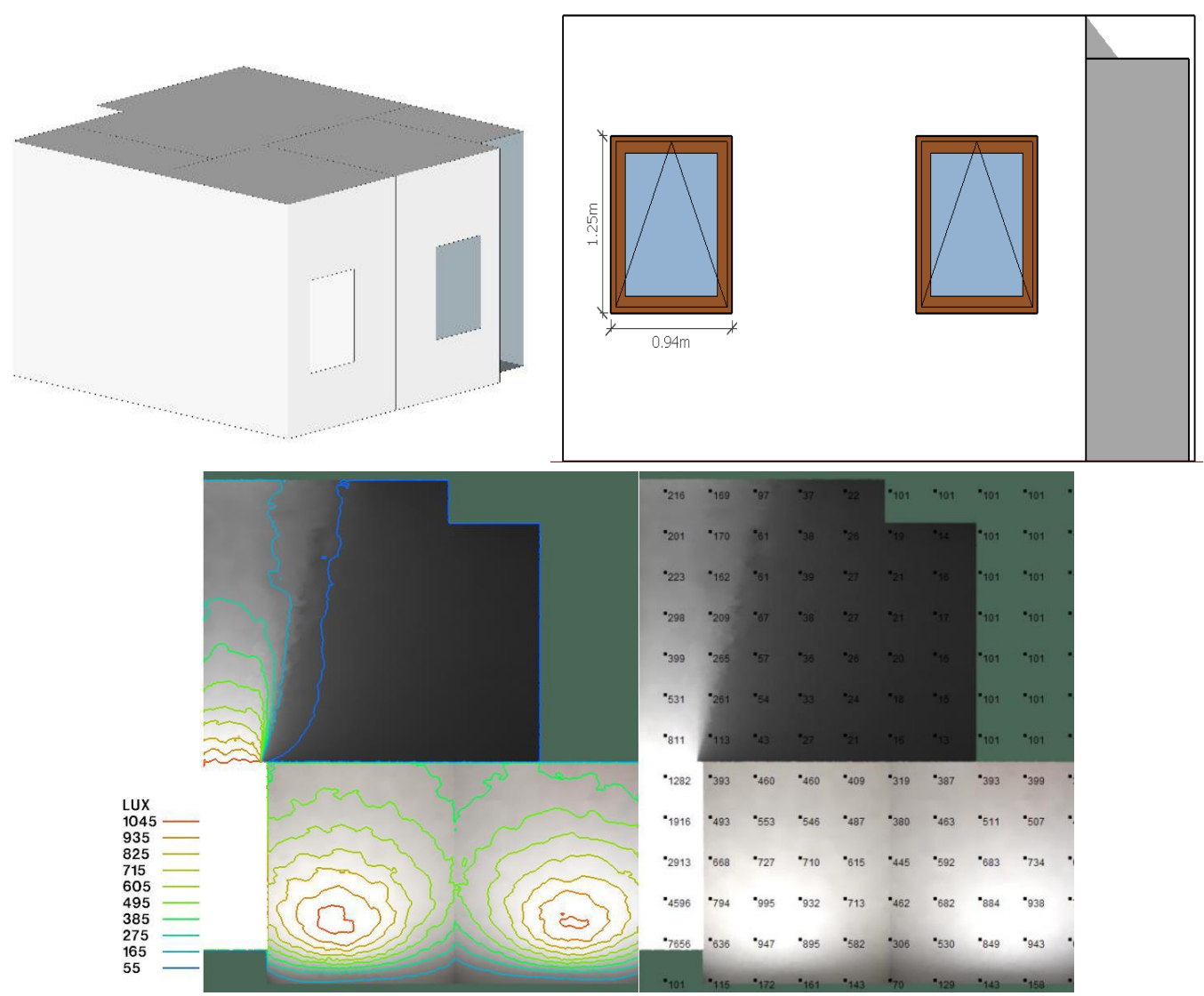

Gambar 10. Model unit hunian strategi desain 1

Tabel 5. Hasil simulasi iluminan (E) pada kamar tidur unit hunian strategi desain 1

\begin{tabular}{c|c|c|c|c|c|c}
\hline \multicolumn{8}{c|}{ 21 MARET } \\
\hline \multicolumn{2}{c|}{08.00} & \multicolumn{2}{c}{12.00} & \multicolumn{2}{c}{16.00} \\
\hline K1 & K2 & K1 & K2 & K1 & K2 \\
\hline 369 & 277 & 75 & 546 & 36 & 277 \\
\hline
\end{tabular}

\subsubsection{Strategi Desain 2}

Strategi desain 2 adalah dengan luas bukaan cahaya yang sama $0,9 \mathrm{~cm} \times 1,4 \mathrm{~cm}$ dan memberi pembayangan (shader) serta memperbesar dimensi pembayangan tersebut. Pembayangan dapat berupa sirip penangkal sinar matahari (SPSM) dengan panjang $50 \mathrm{~cm}$ dan ketebalan $15 \mathrm{~cm}$.

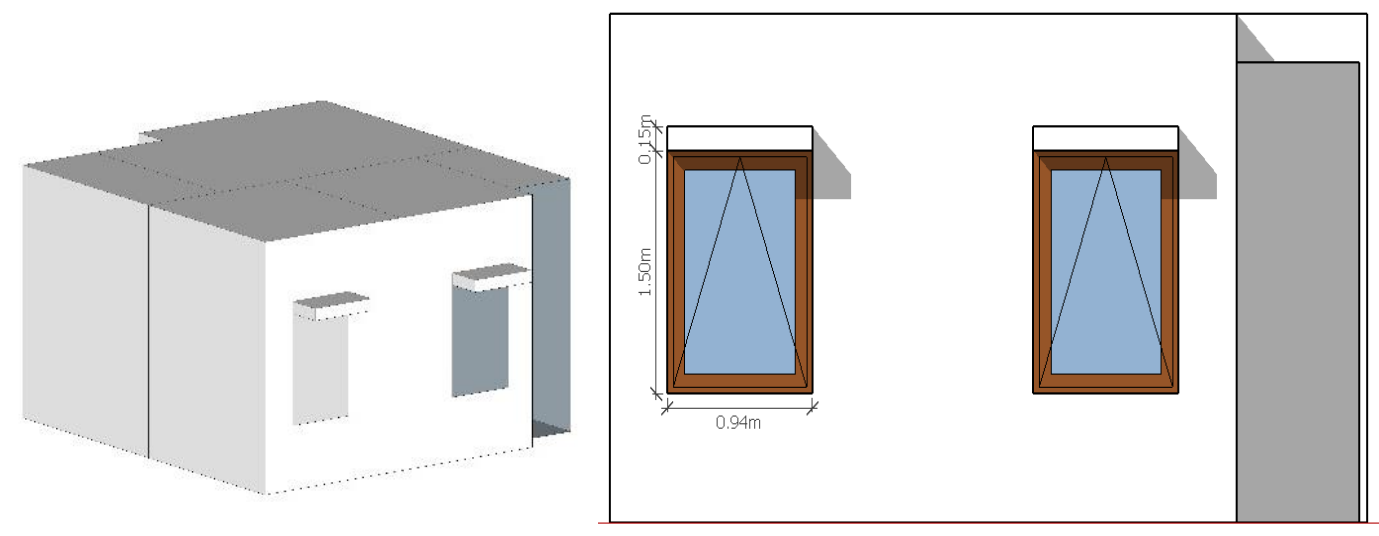




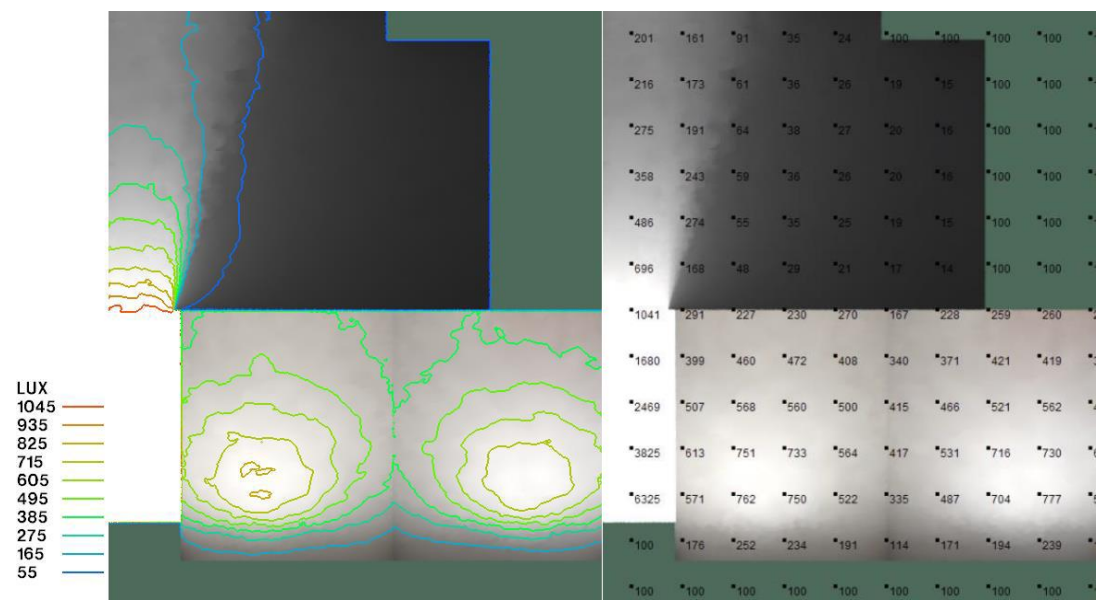

Gambar 11. Model unit hunian strategi desain 2

Tabel 6. Hasil simulasi iluminan (E) pada kamar tidur unit hunian strategi desain 2

\begin{tabular}{|c|c|c|c|c|c|}
\hline \multicolumn{6}{|c|}{21 MARET } \\
\hline \multicolumn{2}{|c|}{08.00} & \multicolumn{2}{|c|}{12.00} & \multicolumn{2}{|c|}{16.00} \\
\hline K1 & K2 & K1 & K2 & K1 & K2 \\
\hline 263 & 329 & 62 & 678 & 344 & 344 \\
\hline
\end{tabular}

\subsubsection{Strategi Desain 3}

Strategi desain 3 merupakan kombinasi antara strategi desain 1 dan strategi desain 2, yaitu dengan memperkecil luas bukaan cahaya menjadi $1,25 \mathrm{~cm}$ x $0,9 \mathrm{~cm}$ serta memberikan pembayangan berupa sirip penangkal sinar matahari (SPSM) dengan panjang $50 \mathrm{~cm}$ dan ketebalan plat $15 \mathrm{~cm}$.

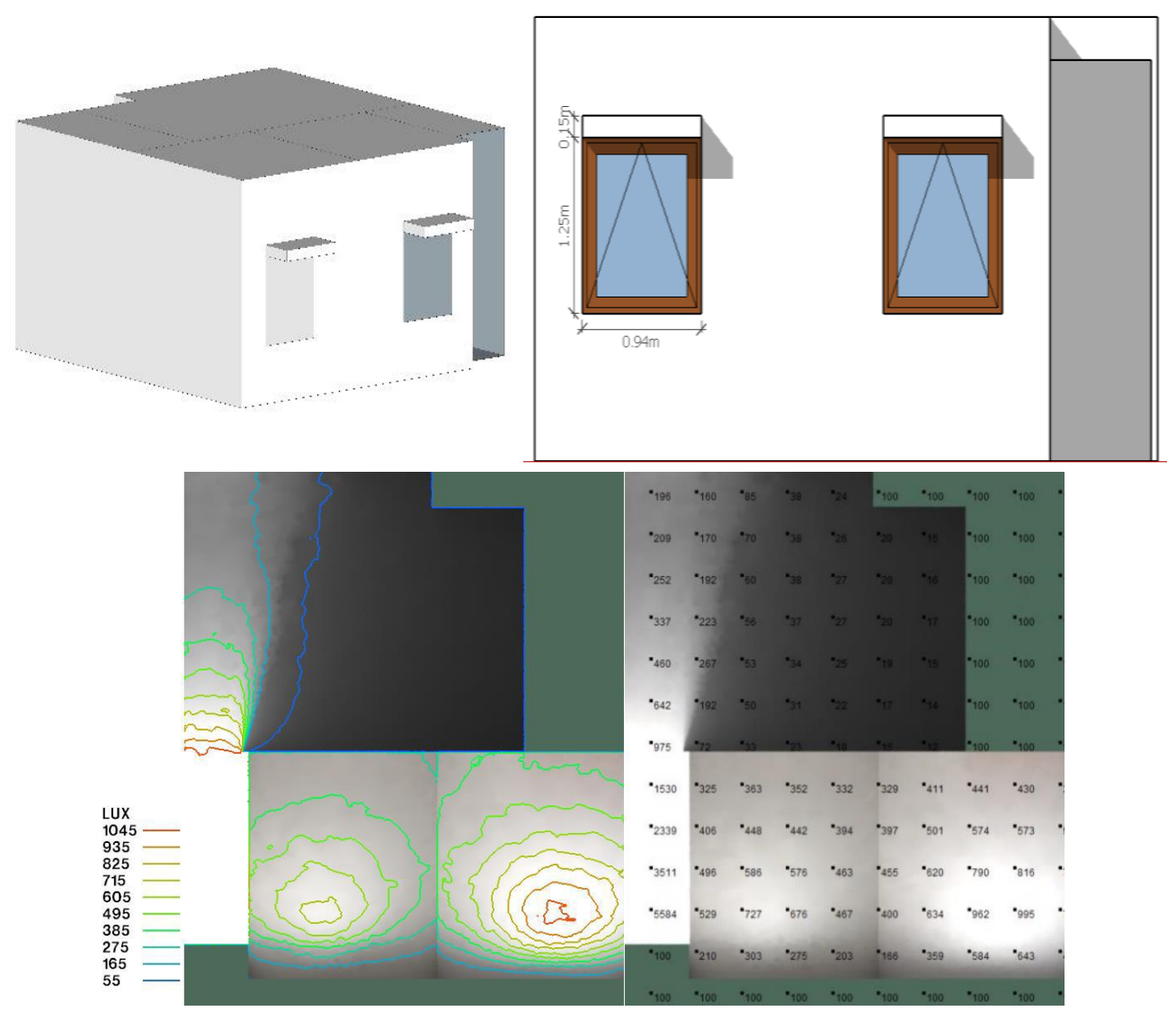

Gambar 12. Model unit hunian strategi desain 2 
Tabel 7. Hasil simulasi iluminan (E) pada kamar tidur unit hunian strategi desain 2

\begin{tabular}{|c|c|c|c|c|c|}
\hline \multicolumn{9}{c|}{ 21 MARET } \\
\hline \multicolumn{2}{c|}{08.00} & \multicolumn{2}{c|}{12.00} & \multicolumn{2}{c}{16.00} \\
\hline K1 & K2 & K1 & K2 & K1 & K2 \\
\hline 220 & 309 & 46 & 506 & 199 & 278 \\
\hline
\end{tabular}

\subsection{Analisis Hasil Simulasi Dengan Strategi Desain}

Hasil simulasi yang dihasilkan dengan menggunakan tiga strategi yaitu dengan memperkecil luas bukaan cahaya, memberi pembayangan (shader) berupa sirip penangkal sinar matahari (SPSM) dan kombinasi keduanya terbukti mempengaruhi hasil iluminan cahaya matahari yang berlebih, yang masuk kedalam ruangan, dapat direduksi sehingga mendekati standar pencahayaan alami rumah tinggal.

\section{SIMPULAN}

Hasil studi menunjukkan bahwa orientasi bangunan dan bukaan cahaya, alokasi bukaan cahaya, dan luas bukaan cahaya berpengaruh terhadap potensi pencahayaan alami yang masuk melalui bukaan pada unit hunian Rusunawa Jatinegara barat. Hasil simulasi dengan menggunakan software IES-VE v5.3.1 menunjukkan bahwa sebagian besar fungsi unit hunian memiliki tingkat iluminasi (E) yang melebihi standar pencahayaan alami rumah tinggal sehingga berpotensi terjadi efek silau (glare). Pada studi kasus, unit hunian pada sisi Utara lebih direkomendasikan daripada unit hunian di sisi Selatan untuk pencahayaan alami yang lebih baik, terkait dengan perletakan unitnya karena sisi Utara terbayang oleh bangunan tower di sebelahnya. Orientasi dan posisi lantai juga berpengaruh terhadap pencahayaan pada unit hunian, walaupun lebih sedikit dibanding faktor lokasi bukaan dan dimensi bukaan. Pada unit hunian dengan tipe yang sama, orientasi fasad luar yang memberikan pencahayaan tertinggi adalah pada sisi Timur bangunan yang memiliki orientasi bukaan ke Selatan.

Simulasi dengan menggunakan strategi antisipasi silau pada desain bukaan yaitu membatasi luas sumber silau dengan cara memperkecil luas bukaan cahaya, memberi pembayangan (shader) berupa sirip penangkal sinar matahari (SPSM) dan kombinasi keduanya terbukti mempengaruhi hasil iluminan cahaya matahari yang masuk kedalam ruangan menjadi berkurang. Hal ini membuktikan bahwa strategi desain memegang pengaruh penting dalam perancanaan bukaan cahaya pada bangunan sehingga dapat mencapai kenyamanan visual. Selanjutnya, pada studi kasus Rusunawa Jatinegara Barat, efek silau (glare) dapat direduksi, oleh karena itu penghuni tidak perlu lagi menutup/menghalangi silau pada jendela secara konvensional (tirai). Pencahayaan Alami Siang Hari (PASH) dapat lebih merata dan dengan demikian tidak perlu pencahayaan buatan pada siang hari, sehingga menghemat biaya listrik dan mendukung konsep keberlanjutan (bangunan hijau).

\section{DAFTAR PUSTAKA}

[1] Krishan, Arvind, et al. (2001). "Climate Responsive Architecture; A Design Handbook for Energy Efficient Building”. Tata McGraw-Hill. New Delhi.

[2] Karyono, Tri Harso, Prof, Ph.D (2016). “Arsitektur Tropis; Bentuk, Teknologi, Kenyamanan \& Penggunaan Energi”. Erlangga, Jakarta.

[3] Latifah, Nur Laela (2015). "Fisika Bangunan 1". Griya Kreasi. Bandung.

[4] Dokumen Sayembara Proyek Desain Arsitektur Rusunawa Jatinegara Barat (2013). http://sayembara-iai.org//diakses Oktober 2016.

[5] IES-VE. The Most Comprehensive Performance Analysis Suite Specially Designed for Architects (2015). https://www.iesve.com/software/ve-for-architects /diakses Februari 2016.

[6] RSNI (2001). "Tata Cara Perancangan Sistem Pencahayaan Alami pada Bangunan Gedung”. 03-2396. 